\title{
Environmental Evaluation of Subdivision Site Developments
}

\section{MARTIN M. KAUFMAN* \\ DAVID L. WIGSTON}

Department of Earth and Resource Science

University of Michigan-Flint

516 Murchie Science Bldg.

Flint, Michigan 48502-1950, USA

ELLIS B. PERLMAN

Department of Public Administration

University of Michigan-Flint

310 French Hall

Flint, Michigan 48502, USA

ABSTRACT / An environmental evaluation was performed at 16 subdivision sites within four communities in east-central
Michigan. The primary objective was to evaluate the fit between environmental ordinances and the physical/environmental conditions to which they were applied. An environmental response index was developed with indicators to assess water, soil, slope, development density, roads, vegetation, and ecology. Water-related indicators achieved the highest scores, while soil-related indicators scored the poorest, with generally poor performance across all indicators. The poor performance indicates there are problems in the ability of environmental ordinances developed at broader jurisdictional scales (e.g., the state) to address the existing environmental conditions at smaller geographic scales (subdivisions within communities). Two key problems include the lack of scientific specificity in the broader state-level ordinances and the lack of local expertise and/or resources to monitor the environment.
The environmental awareness beginning in the 1970 s at higher levels of government eventually found its expression within local jurisdictions. Local zoning and subdivision ordinances-some in place since the National and State Planning Enabling Acts of the 1920 s-were updated to reflect environmental concerns (Hagman 1975). By the mid-1980's, most Michigan municipalities had adopted ordinances related to soil erosion and floodplains, and many were in the process of implementing ordinances for wetland protection, recycling, and stormwater management.

The differing origins of local environment-related ordinances and their application raises several questions. For instance: Who developed them? How did they come to exist and evolve over time in a particular place-e.g., what sort of environment and problems did the authors address? Are the ordinances equally suited to local physical conditions in other places, places far from and different from the places for which the authors designed them? And, if an ordinance is unsuited to local physical conditions, what are the environmental effects?

There are 1778 villages, townships, or cities (minor

KEY WORDS: Subdivision development; Environmental indicators; Environmental site assessment; Environmental ordinances; Community environmental response

*Author to whom correspondence should be addressed; email: martyk@umflint.edu civil divisions, MCDs) in Michigan. Some MCDs have developed their own ordinances, others have cloned or copied ordinances, such as those regulating subdivisions, stormwater, wetlands, and floodplains/coastlines from other communities, while still other MCDs adopt (copy) these ordinances from higher levels of government "by reference" (Kaufman 1995, MCL 2000).

Ordinance cloning or copying by reference can be environmentally detrimental because the process often ignores significant differences in local environmental settings and their physical processes and systems. For instance, there are profound differences in soil, topography, and surface drainage systems between the flat, clayey lake plains of the Saginaw Valley in east-central Michigan and the hilly, morainic terrain of the Traverse Bay region in the northwest part of the lower peninsula; yet subdivision ordinances and stormwater infrastructure are typically the same in both.

In this case, the practice of cloning or copying by reference may increase the discharge of stormwater to nearby streams and result in local flooding, or the specification of a predefined density requirement, without considering the local environmental conditions, such as soil infiltration capacity, may lead to the overbuilding of drainage structures. From an economic efficiency perspective, the extra infrastructure is a wasted capital expenditure, which is especially critical given the current fiscal conditions of many communities.

The development of in-house environmental ordi- 


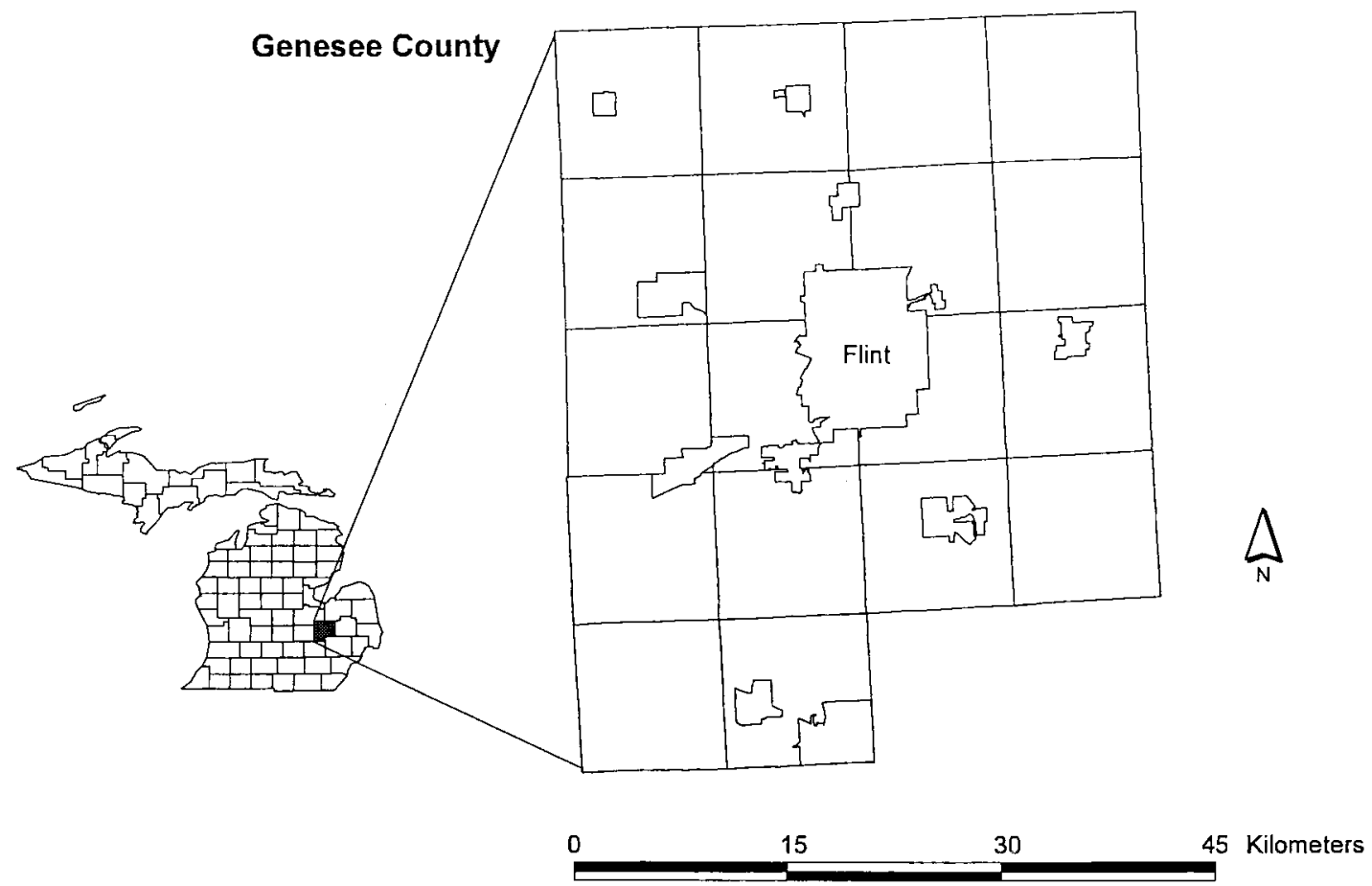

Figure 1. Study area.

nances is no guarantee of their satisfactory performance. Many communities use attorneys and urban planners to develop their own ordinances, yet these professionals have little or no training in environmental science. Currently in Michigan, there are numerous indications of substantial environmental damage resulting from the improper application of environmental ordinances (Kaufman and Marsh 1997, Kaufman 2000).

In Michigan, the enacted environmental ordinances include the Soil Erosion and Sedimentation Control Act (PA 347), the Goemaere-Anderson Wetland Protection Act (PA 203), and the Subdivision Control Act (PA 288, PA 591 amended). Minor civil divisions often copy these ordinances by reference, with no modification to their stated objectives or compliance/enforcement procedures. Additional environmental ordinances relevant to land development at the geographic scale of the subdivision typically include a floodplain ordinance (if the community is within a floodplain area), and provisions within the locally adopted subdivision control ordinance for the preservation of native tree species and/or green spaces.

The Subdivision Control Act provides the framework for the application of the state-level environmental ordinances by defining the sequence developers and MCDs must follow for residential development. Thus, this research focuses on the relationship between environmental regulation and environmental science at the geographic scale of the residential subdivision. An environmental evaluation was performed at 16 subdivision sites within four communities in east-central Michigan. The primary objective was to evaluate the fit between environmental ordinances and the physical/environmental conditions to which they were applied and to identify potential factors contributing to the status of local environmental management.

\section{Study Area}

The study area is Genesee County, in east-central Michigan (Figure 1). Southern Michigan is dominated by glacial terrain formed during the decay of the late Wisconsinan ice sheet 10,000-15,000 years BP. The region is crossed by several systems of moraines and related landforms containing thousands of topographic depressions in which lakes and wetlands have formed. These features are generally small (under 100 acres), and as a whole, the landscape exhibits high local diversity, which can be characterized as knob (for the moraine features) and kettle (for the lakes and depressions) (Dorr and Eschman 1970).

Soils in the region are understandably varied, ranging from sandy loams on outwash plains to finer tex- 
Table 1. Subdivision control act-major stages $^{\mathrm{a}}$

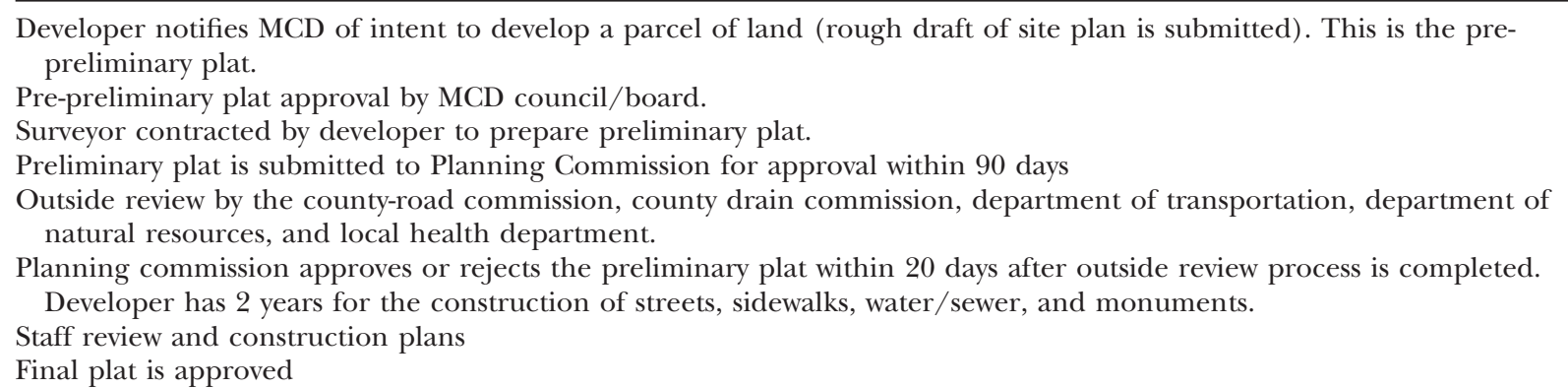

${ }^{\text {a }}$ Tasks related to document filing or fee assessment are not shown.

tures on moraines and lake plains. Infiltration capacities and permeability rates tend to vary with soil texture, and where soils are stripped of vegetative cover, most are capable of yielding high rates of runoff in all seasons. Where groundwater lies close to the surface around many lakes and wetlands, infiltration capacities can be very low, especially in winter and spring, and runoff rates correspondingly high. These are favorite development sites, and they are especially prone to high soil erosion rates (Holcomb 1993). This area has an abundance of small-scale water features that are also attractive to developers but also highly vulnerable to sedimentation from even small construction sites.

The four communities selected for this study represent older urban areas and newly developing townships with populations under 30,000. To account for the diversity of development scenarios, four subdivisions per community were evaluated within various physical environments including wetlands, lakes, streams, and variable slopes.

\section{Materials and Methods}

An index is created from a set of environmental indicators and is used to represent a measure of environmental response within communities during the subdivision development process. This will enable a comparison between communities and determine if the environmental measures implemented during the development of subdivisions are affected by their differing physical landscapes. For instance, past research has demonstrated a higher response to environmental hazards based on the presence of observable surface water features (Kaufman 1995).

\section{Indicator Selection}

The indicators employed to construct the environmental response index will have the following characteristics: (1) they must measure the stated environmen- tal objectives of existing state and local ordinances; (2) they adequately represent the range of physical, hydrologic, and ecologic processes operating at the small geographic scales of residential developments; and, (3) their use is well known in environmental planning practice and/or there is significant scientific evidence of their importance.

To meet these requirements, the indicators of environmental response are derived from the stated objectives of any existing environmental ordinances or review procedures as they are applied within the context of the Subdivision Control Act. Table 1 depicts the major steps of this process, and Table 2 shows the general evaluation categories derived from the environmental objectives within the ordinances.

Referring to Table 1, the pre-plat stage is optional. Many communities use pre-platting to screen proposals to evaluate their general adherence to local development objectives. The planning commission's review of the preliminary plat should, in theory, require the developer to meet the currently enacted state and local environmental ordinances. For instance, any project proposing to disturb any wetland area greater than 5 acres in size would violate PA 203 (the GoemaereAnderson Wetland Protection Act) and not be approved unless a wetlands mitigation arrangement was implemented. When development begins at the site, the enforcement of the locally adopted state environmental ordinances continues under the jurisdiction of the Soil Erosion and Sedimentation Control Act and any required adherence to local ordinances (e.g., vegetation).

Table 2 shows the evaluation categories derived from the environmental objectives present during the different stages of subdivision review and development. The evaluation categories are identified based on their centrality and importance to the review currently being conducted. Seven evaluation categories result (development density, water, roads, soil, slope, vegetation, and 
Table 2. Site development environmental evaluation categories

\begin{tabular}{lll}
\hline Stage and activity & Environmental objectives & Evaluation category \\
\hline $\begin{array}{l}\text { Pre-preliminary plat } \\
\text { Review by MCD council/board }\end{array}$ & $\begin{array}{c}\text { Compatibility with local master plan } \\
\text { development density guidelines and open } \\
\text { space requirements }\end{array}$ & development density \\
$\begin{array}{l}\text { Preliminary plat } \\
\text { Outside review by Drain Commissioner }\end{array}$ & $\begin{array}{l}\text { Provide adequate storm drainage and } \\
\text { protect surface water resources }\end{array}$ & water \\
Outside review by county road & Ensure road width (capacity) and grade are & roads \\
commission and state department of & adequate; provide a safe road & vegetation, ecology, water \\
transportation & configuration & \\
Outside review by county health & Protect groundwater and wells; provide safe \\
department and state department of & drinking water; conform to wetland laws & \\
natural resources & & \\
Final preliminary plat & & \\
Staff review, final planning commission & Ensure compatibility with local ordinances & \\
review, council/board approval & and allow for citizen input on any & \\
Construction review & environmental concern & \\
Construction & Control soil erosion (stabilize slopes, & soil, slope, vegetation \\
& stabilize soil, water management); & \\
& enforce other locally-authored & \\
& ordinances &
\end{tabular}

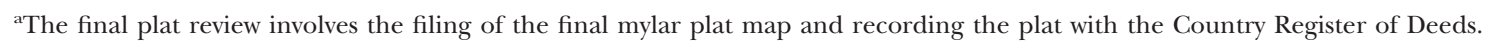

ecology), and each contains one or more specific indicators of environmental response for the site environmental assessments.

\section{Indicator Justification}

A total of 34 indicators designed to measure the objectives are presented in Table 3 . Scoring is based on whether the condition present at the site promotes (scored as 1) or fails to attain (scored as 0 ) one or more of the overall objectives. All evaluation criteria, including any additional measures employed by the investigators are explained and scientifically justified. The indicators are numbered to provide reference for the ensuing discussions.

Soil indicators. When land is disturbed by construction activity, soil erosion increases drastically. Erosion rates as high as 40,000 times the preconstruction rate have been observed. The typical magnitude is between 20 and 40, which equates to a loss of 50-70 tons of soil per acre per year (Goldman and others 1986).

Five factors influence the rate of soil erosion: soil erodibility, rainfall intensity, slope, vegetative cover, and conservation/construction practices. All of these factors can be affected by local management practices, with vegetative cover exerting the most influence on the erosion rate (Pimental and others 1987). At the surface, vegetation stabilizes the soil and reduces sheet and gully erosion, which both occur within the study area. Above the surface, vegetation foliage reduces wind velocities and intercepts rain, lowering their respective erosive capacities.

Referring to Table 3, basic information about soil is necessary to direct specific erosion control practices (indicators 1 and 2). For instance, the performance of certain geotextiles varies due to the difference in the characteristics of suspended solids associated with different soils (Barrett and others 1998). Indicators 3 and 4 are used to evaluate the objectives of stabilizing slopes and soil, and for managing water.

Water indicators. With respect to water management (Table 3), there are numerous runoff control measures also available at the microtopographic scale (less than 0.45 ha) within subdivision developments (indicators 5-9) (Kaufman 1999). Curbs speed up the collection of stormwater and increase its average flow velocity. This increases the erosive capacity of the stormwater and reduces the time it takes to reach the nearest waterbody, resulting in more frequent flooding and increased sedimentation. Curbs also prevent the entry of runoff from crowned roads into off-road swales for slower conveyance or infiltration (indicator 5). The shape of median strips may also affect the amount of runoff reaching streets (indicator 6).

Rooftop runoff contributes significant quantities of water to storm drains. A study of urban downspout redirection away from the stormwater collection system showed a significant decrease in the total volumes of stormwater (Kaufman and Wurtz 1997). Preventing this 


\begin{tabular}{|c|c|}
\hline Indicators & Scoring \\
\hline \multicolumn{2}{|l|}{ Soil indicators } \\
\hline \multicolumn{2}{|l|}{ Objectives: Stabilize slopes, soil stabilization, water management } \\
\hline 1. Is soil type noted on development plan? & $($ no $=0 ;$ yes $=1)$ \\
\hline 2. Was original topsoil replaced (backfilled) by the developer with a less permeable soil? & $($ no $=1 ;$ yes $=0)$ \\
\hline 3. Are swales/depressions present on slopes greater than 15 percent? & $($ no $=0 ;$ yes $=1)$ \\
\hline 4. Is vegetation used to prevent soil transport to nearby storm drains and water features? & $($ no $=0 ;$ yes $=1)$ \\
\hline \multicolumn{2}{|l|}{ Water indicators } \\
\hline \multicolumn{2}{|l|}{ Objectives: protect existing water resources, provide adequate drainage for stormwater } \\
\hline 5. Are curbs present? & $($ yes $=0$, no $=1)$ \\
\hline \multicolumn{2}{|l|}{ 6. If present, are median strips crowned? $($ yes $=0 ;$ no $=1)$} \\
\hline 7. Are downspouts directed onto grassed surfaces? & $($ yes $=1$, no $=0)$ \\
\hline 8. Are double-tiered lots graded toward the street? & $($ yes $=0 ;$ no $=1)$ \\
\hline 9. Are depression storage areas present at the lot or block scales? & $($ yes $=1 ;$ no $=0)$ \\
\hline 10. Is "on-site" detention present? (on-site refers to development-wide detention/retention basins) & $($ yes $=1 ;$ no $=0)$ \\
\hline 11. Were streams channelized during development? & $($ yes $=0 ;$ no $=1)$ \\
\hline 12. Is stormwater discharge spatially dispersed; do many outfalls exist for stormwater discharge? & $($ yes $=1 ;$ no $=0)$ \\
\hline 13. Do local streams exhibit point bars or other evidence (braiding) of excess sediment loads? & $($ yes $=0 ;$ no $=1)$ \\
\hline 14. Is there any development in the floodplain? & $($ yes $=0 ;$ no $=1)$ \\
\hline 15. Do storm drains discharge directly into wetlands? & $($ yes $=0 ;$ no $=1)$ \\
\hline 16. Do storm drains discharge directly into lakes? & $($ yes $=0 ;$ no $=1)$ \\
\hline \multicolumn{2}{|l|}{ Slope indicators } \\
\hline \multicolumn{2}{|l|}{ Objectives: prevent slope instability, limit excess erosion, ensure structural safety } \\
\hline 17. Is there evidence of slope instability in areas of slope $\geq 15 \%$ ? & $($ yes $=0 ;$ no $=1)$ \\
\hline 18. Are critical slopes $(>15 \%)$ stabilized (vegetation or other method)? & $($ yes $=1 ;$ no $=0)$ \\
\hline 19. Is there over-development in a critical management zone (areas of high slope, 1 st order streams)? & $($ yes $=0 ;$ no $=1)$ \\
\hline $\begin{array}{l}\text { 20. At the development scale, is stormwater conveyed toward areas of naturally occurring depression } \\
\text { storage? }\end{array}$ & $($ yes $=1 ;$ no $=0)$ \\
\hline \multicolumn{2}{|l|}{ Development density indicators } \\
\hline \multicolumn{2}{|l|}{ Objectives: create development densities compatible with master plan objectives } \\
\hline $\begin{array}{l}\text { 21. Does the development density match the capabilities of the land use unit on which it is located? } \\
\text { (are high-density areas buffered by forests and permeable soils from steep slopes and runoff } \\
\text { collection areas?) }\end{array}$ & $($ yes $=1 ;$ no $=0)$ \\
\hline \multicolumn{2}{|l|}{ Road indicators } \\
\hline \multicolumn{2}{|l|}{$\begin{array}{l}\text { Objectives: insure the proposed development does not compromise public safety and provides adequate } \\
\text { capacity for the additional traffic }\end{array}$} \\
\hline 22. Does the road configuration enhance the drainage network during rainstorms (intensification)? & $($ yes $=0 ;$ no $=1)$ \\
\hline 23. Are roads too wide (over 7.5 meters), where narrower roads can suffice? & $($ yes $=0 ;$ no $=1)$ \\
\hline \multicolumn{2}{|l|}{ Vegetation indicators } \\
\hline \multicolumn{2}{|l|}{ Objectives: preserve native species, provide climate controls } \\
\hline 24. Are native species used in public areas? & $($ yes $=1 ;$ no $=0)$ \\
\hline 25. Is there adequate density of vegetation where space permits? & $($ yes $=1 ;$ no $=0)$ \\
\hline 26. Do planting patterns in public areas provide wind protection for undeveloped landscapes? & $($ yes $=1 ;$ no $=0)$ \\
\hline $\begin{array}{l}\text { 27. Do planting patterns in public areas assist stormwater management and local flood control (are } \\
\text { trees planted near stormwater collection zones and floodplains to help retard large overland flow } \\
\text { events)? }\end{array}$ & $($ yes $=1 ;$ no $=0)$ \\
\hline \multicolumn{2}{|l|}{ Ecological indicators } \\
\hline \multicolumn{2}{|l|}{ Objectives: minimize human impacts on local ecosystems } \\
\hline 28. Were wetlands removed during development? & $($ yes $=0 ;$ no $=1)$ \\
\hline 29. Were natural forested areas removed during development? & $($ yes $=0 ;$ no $=1)$ \\
\hline $\begin{array}{l}\text { 30. Are forested or wetland areas fragmented by the development? (patch size for vertebrates is below a } \\
\text { critical threshold of } 0.55 \mathrm{ha} \text { ) }\end{array}$ & $($ yes $=0 ;$ no $=1)$ \\
\hline 31. Is there evidence of nutrient loading in any waterbodies on the site? & $($ yes $=0 ;$ no $=1)$ \\
\hline 32. Are wildlife corridors preserved? & $($ yes $=1 ;$ no $=0)$ \\
\hline 33. Has native species diversity decreased after the development? & $($ yes $=0 ;$ no $=1)$ \\
\hline 34. Is there evidence of old field succession? & (yes or no; not scored) \\
\hline
\end{tabular}

water from reaching the storm drains can also reduce peak flows to nearby waterbodies (indicator 7 ).

Indicators 8 and 9 evaluate the extent to which developers and local communities have taken advantage of existing topography for stormwater manage- ment. Lot grading and natural depressions within small lots can significantly affect the volume of stormwater reaching the storm collection system. Typical subdivision lot grading practice creates a slope towards the street. This engineered slope is designed to enhance 
the drainage of water from the lot and also has the effect of contributing more stormwater runoff containing sediment and nutrients from fertilizers. The amount of natural depression storage available in subdivisions with many lots can be substantial but is rarely considered. On a 0.45 -ha lot ( 1 acre), a natural depression $30 \mathrm{~cm}$ deep (1 foot) covering an area of $83.6 \mathrm{~m}^{2}$ $\left(900 \mathrm{ft}^{2}\right)$ can instantaneously store $25.5 \mathrm{~m}^{3}$ (6733 gal) of water. With modest infiltration of $5 \mathrm{~cm} /$ day (2 in.), the potential storage increases by $4.2 \mathrm{~m}^{3}$ (1122 gal).

During precipitation events urban runoff (stormwater) conveys pollutants to receiving waterbodies. Thus, efforts to improve urban water management have been broadly concerned with the linkage between the quality and quantity of stormwater (Burian and others 1999). Attenuation of peak stormwater flows through the use of on-site detention/retention storage (indicator 10) has been a standard method to achieve quantity reductions and subsequent improvements of quality within the receiving waterbodies (McCuen and Moglin 1988).

Indicators 11-16 directly measure the protection of surface water resources. Channelization (indicator 11) is the group of engineering practices used to control flooding, drain wetlands, improve river channels for navigation, control streambank erosion, improve river alignment, and is often accompanied by restoration (Brookes and others 1983, Brookes and Shields 1996). At the relatively small geographic scale of subdivision development, typical channelization methods include the installation of rip-rap to stabilize streambanks and lining or fully enclosing the stream channel beneath roads with concrete. Both methods noted here are detrimental to stream ecology (e.g., the removal of bankside vegetation) and alter the energy balance within streams, which can lead to increased channel erosion and sedimentation (Hooke 1986).

The spatial dispersion of stormwater outfalls (indicator 12) can help receiving waterbodies assimilate the extra loads of water, sediment, and pollutants during storm events. Point bars and braiding are indicative of excessive sediment loads if the inflow of sediment is significant relative to the transporting capacity of the receiving channel. These channel alterations are commonly observed in areas of construction activity (indicator 13) (Wolman 1967, Graf 1975). Floodplain development (indicator 14) is considered to occur if there is a structure or house lot area present within the floodplain. The lot itself can be eroded by floodwaters, increasing sedimentation and posing a health threat if drain tiles from septic systems are present.

The root systems of wetland vegetation are adapted to certain water levels (Mitsch and Gosselink 1993), so the direct discharge of stormwater is an important con- sideration for the proper protection of wetlands (indicator 15). Cultural eutrophication often results when freshwater inland lakes receive stormwater runoff carrying excess phosphorus from fertilized lawns (indicator 16).

Slope indicators. Ground slope is a key component of soil and water management, and the consideration of slope is required to ensure the safety of structures (Table 3). Many factors should be considered when assessing the susceptibility of slopes to failure. The most important are the angle and composition of the slope (soil and bedrock) and the history of slope activity. Developable areas with slopes greater than $15 \%$ should be stabilized (Crozier 1984) (indicators 17 and 18). Critical management zones are areas of unique ecology and/or topography where development should be limited (Ortolano 1984) (indicator 19). Stormwater management can be aided at least two ways by the use of natural drainage corridors in sloped areas: (1) there is less ecosystem disruption when the natural landscape is used to convey water, and (2) money is saved by not constructing artificial drainage structures. The use of natural depression storage can also help to recharge regional groundwater supplies (indicator 20).

Development density indicators. Development densities (Table 3) are directly correlated with increased stormwater runoff (Hall and Ellis 1985). Within already urbanized watersheds, the areas containing whatever forested land remains have the steeper slopes characteristic of the headwater tributaries (Kaufman and Marsh 1997) (indicator 21). Unless these areas are developed at lower densities and buffered by forests and permeable soils, there will be an increased flood risk because many headwater streams cannot accommodate the extra runoff.

Road indicators. Not all of the land areas within a watershed contribute runoff when storms occur. This concept is known as partial area hydrology (Betson 1964). The areas within a watershed not contributing significant amounts of runoff are called partial areas and may arise because of differences in infiltration, hydrogeology, topography, and soil. These land areas are often unconnected, but may be joined by human modification of the landscape. For example, roads (Table 3) become ephemeral streams during rainfall events, so development planners should consider the possibility that their placement may join partial areas and intensify runoff (indicator 22). The width of roads can also influence the amount of stormwater runoff (indicator 23).

Vegetation indicators. The indicators for vegetation are shown in Table 3. Native species are those best adapted to local conditions, use water and soil most 
efficiently, and therefore have the highest survival rates-a factor affecting the costs of maintaining the urban forest (Moll 1988) (indicator 24).

Tree canopies typically cover $30 \%$ of urban land area. This significant amount of coverage has implications for stormwater management and climate control. Tree foliage and branches intercept precipitation and reduce the amounts of stormwater runoff. Significant interception rates of over $30 \%$ have been observed in stands of conifers (Cape and others 1991) (indicators 25 and 26). Properly sited tree stands may also reduce household heating and cooling costs and the damage from floods.

The channelization of streams often results in the removal of near-stream (riparian) vegetation and has been cited as a contributing factor for the high damage incurred during the 1993 Mississippi River floods. The Mississippi is extensively channelized and much of its riparian vegetation no longer remains (indicator 27) (Myers and White 1993).

Ecological indicators. Table 3 also presents the ecological indicators. Human impacts on ecosystems can be classified into six types: reduction, fragmentation, overgrowth, substitution, simplification, and contamination (Marsh 1996). Reduction involves the removal of part or all of an ecosystem, such as wetlands or forests (indicators 28 and 29). Fragmentation occurs when habitats are divided by development, leaving some areas too small to support certain animal populations (Dickman 1987) (indicators 30 and 32). Overgrowth refers to human-induced substances that overstimulate the productivity of certain ecosystems, such as when algal blooms within aquatic ecosystems are caused by excess phosphorus inputs from detergents and fertilizers (indicator 31). Simplification of ecosystems occurs when the number of species declines within ecosystems. The diversity of native species is one measure of the amount of simplification (indicator 33).

Old field succession (indicator 34) was included to evaluate whether a development was occurring on abandoned farmland (yes) or on recently productive farmland (no). The score for this indicator was not included in the overall index computation.

One development evaluated by this study was on a woodland boundary, with some incursion into the woodland area (i.e., woodland clearance for roads and houses). The woodland showed evidence of having been managed as coppice-with-standards (Wigston 1980) some 100 years ago. Coppice-with-standards is a woodland management system that combines the production of brushwood of various sizes (coppice) with large timber trees (standards). This woodland management practice was extensive in northwest Europe from about 5000 years BP until the end of the 19th century. It was not widely imported to North America with European colonization, so this is a site of some historical importance. Coppice-with-standards also results in high plant species and wildlife diversity. Its use has been the subject of several investigations (Lowell and others 1987, Yoshida and Tomohiko 1997). This ecologically and historically significant woodland could have been conserved in the development planning as an asset to the site and thus provides another example of the need to perform thorough site evaluations.

\section{Field Techniques and Statistical Analyses}

Project investigators made two visits to each of the 16 development sites, which ranged in size from 10 to 40 ha. Measurements of slope were made with clinometers, and standard tape measures were used for road widths. Standard photography was used to document significant physical features, evidence of environmental response/nonresponse, specifically in the areas of erosion control and water management, and nonnative species. Aerial photographs taken in 1997 at the scale of 1 in. to $200 \mathrm{ft}$ helped to verify the extent of habitat patches resulting from fragmentation and to determine if sensitive ecological land uses such as wetlands and forests may have been reduced. To ascertain the presence of natural depression storage at sites and identify areas where roads may become ephemeral streams, paper and digital 7.5-min topographic maps compiled from 1983 aerial data were used to construct vertical profiles for comparison of the local relief at each site before and after lot grading.

The 34 environmental indicators were observed and evaluated at each site. Scores within each environmental category were totaled and means $(\mu)$ of each category were computed. The data values were standardized using $z$ scores and the means of the categories compared using a one-way analysis of variance (ANOVA). Significant differences between the category means were tested using the Tukey-Kramer HSD. The Student's $t$ test was used to test for significant differences between the mean scores of sites where citizen concern, planning commission concern, or actual response were present or absent. All statistical tests were performed at the 0.05 level of significance.

\section{Document Review}

All documentation of the subdivision approval process for each site was reviewed, including the pre-plat, preliminary plat, and final plat. Investigators also read all of the external project reviews performed by state and local officials, planning commission minutes, outside consultant correspondence, public input, and de- 
Table 4. Site evaluation results ${ }^{a}$

\begin{tabular}{|c|c|c|c|c|c|c|c|c|}
\hline Site & $\begin{array}{l}\text { Soil } \\
(4)\end{array}$ & $\begin{array}{l}\text { Water } \\
(12)\end{array}$ & $\begin{array}{l}\text { Slope } \\
(4)\end{array}$ & $\begin{array}{l}\text { Density } \\
\text { (1) }\end{array}$ & $\begin{array}{l}\text { Roads } \\
(2)\end{array}$ & $\begin{array}{c}\text { Vegetation } \\
\text { (4) }\end{array}$ & $\begin{array}{l}\text { Ecology } \\
(6)\end{array}$ & $\begin{array}{l}\text { Total } \\
(33)\end{array}$ \\
\hline \multicolumn{9}{|l|}{ MCD1 } \\
\hline 1 & 0 & 7 & 1 & 0 & 0 & 0 & 1 & 9 \\
\hline 2 & 0 & 5 & 0 & 0 & 0 & 0 & 1 & 6 \\
\hline 3 & 0 & 9 & 1 & 0 & 0 & 1 & 1 & 12 \\
\hline 4 & 0 & 8 & 2 & 1 & 1 & 2 & 1 & 15 \\
\hline Mean & 0 & 7.25 & 1 & 0.25 & 0.25 & 0.75 & 1 & 10.5 \\
\hline \multicolumn{9}{|l|}{ MCD2 } \\
\hline 1 & 0 & 7 & 2 & 0 & 1 & 0 & 0 & 10 \\
\hline 2 & 0 & 8 & 1 & 0 & 0 & 2 & 2 & 13 \\
\hline 3 & 0 & 7 & 1 & 0 & 0 & 4 & 4 & 16 \\
\hline 4 & 0 & 6 & 1 & 0 & 0 & 3 & 1 & 11 \\
\hline Mean & 0 & 7 & 1.25 & 0 & 0.25 & 2.25 & 1.75 & 12.5 \\
\hline \multicolumn{9}{|l|}{ MCD3 } \\
\hline 1 & 0 & 5 & 1 & 0 & 0 & 0 & 2 & 8 \\
\hline 2 & 1 & 5 & 3 & 0 & 0 & 4 & 2 & 15 \\
\hline 3 & 0 & 6 & 2 & 0 & 0 & 0 & 5 & 13 \\
\hline 4 & 0 & 6 & 0 & 0 & 2 & 2 & 4 & 14 \\
\hline Mean & 0.25 & 5.5 & 1.5 & 0 & 0.5 & 1.5 & 3.25 & 12.5 \\
\hline \multicolumn{9}{|l|}{ MCD4 } \\
\hline 1 & 0 & 7 & 2 & 0 & 0 & 0 & 1 & 10 \\
\hline 2 & 0 & 5 & 1 & 0 & 0 & 1 & 3 & 10 \\
\hline 3 & 0 & 4 & 1 & 0 & 0 & 0 & 1 & 6 \\
\hline 4 & 0 & 5 & 1 & 0 & 0 & 0 & 3 & 9 \\
\hline Mean & 0 & 5.25 & 1.25 & 0 & 0 & 0.25 & 2.0 & 8.75 \\
\hline Grand mean & 0.063 & 6.25 & 1.25 & 0.063 & 0.25 & 1.19 & 2.0 & 11.06 \\
\hline
\end{tabular}

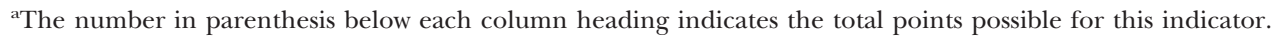

veloper response to citizen and community concerns. Local master plans and environmental ordinances were also evaluated to determine if an explicit type of development ethic existed within specific communities.

A summary comparison of the site evaluation scores with the different concerns and responses is presented to help investigate the relationships between environmental planning and its implementation in the study area.

\section{Results}

The results of the field investigations are presented in Table 4. No single development achieved over half of the total points available, with the total point scores ranging from 6 and 16. There were also significant scoring differentials exhibited between the developments within each of the four study area communities. To protect the confidentiality of developers and other parties, specific developments are not identified by name.

The grand mean score of 11.06 of a possible 33 indicates very poor attainment of the environmental objectives stated within the local ordinances. Waterrelated indicators achieved the highest mean score
(6.25 of a possible 12), and soil-related indicators had the lowest mean score (0.063 of a possible 4$)$. After standard scores were computed for the data and their means, a one-way ANOVA indicated there were significant differences among the mean scores for the categories $\left(F=74.7, R^{2}=0.81, P<0.0001\right)$. The TukeyKramer HSD test was performed to determine which pairs of means were most significantly different (Table 5). Reading down the columns, the means for the water and ecology indicators exhibited the most variation, with the water mean being significantly different from all six of the other category means, and the ecology mean demonstrating significant variation from 4 of the other category means.

Table 6 presents the results from the document reviews conducted for each site. Citizen concerns about a specific development include any written communication from a private citizen to a local official or a verbal statement made at a public hearing-typically a planning commission meeting. Planning commission concerns are those statements made on the record by members of the local planning commission about a specific development. The response column summarizes the actions taken by the developers or local communities to address the concerns raised by the public or 
Table 5. Mean comparisons using Tukey-Kramer HSDa

\begin{tabular}{|c|c|c|c|c|c|c|c|}
\hline & Water & Ecology & Slope & Vegetation & Roads & Soil & Density \\
\hline Water & -0.48 & 1.41 & 1.74 & 1.77 & 2.18 & 2.27 & 2.27 \\
\hline Ecology & 1.41 & -0.48 & -0.14 & -0.12 & 0.29 & 0.38 & 0.38 \\
\hline Slope & 1.74 & -0.14 & -0.48 & -0.45 & -0.03 & 0.05 & 0.05 \\
\hline Vegetation & 1.77 & -0.12 & -0.45 & -0.48 & -0.06 & 0.02 & 0.02 \\
\hline Roads & 2.18 & 0.29 & -0.06 & -0.06 & -0.48 & -0.39 & -0.39 \\
\hline Soil & 2.27 & 0.38 & 0.02 & 0.02 & -0.39 & -0.48 & -0.48 \\
\hline Density & 2.27 & 0.38 & 0.02 & 0.02 & -0.39 & -0.48 & -0.48 \\
\hline
\end{tabular}

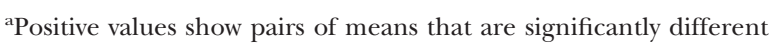

Table 6. Document review

\begin{tabular}{|c|c|c|c|}
\hline \multirow[b]{2}{*}{ Site (evaluation score) } & \multicolumn{2}{|c|}{ Concerns } & \multirow[b]{2}{*}{ Response } \\
\hline & Citizen & Plan commission & \\
\hline \multicolumn{4}{|l|}{ MCD1 } \\
\hline $1(9)$ & None & None & None \\
\hline $2(6)$ & Flood control; wetlands & None & None \\
\hline $3(12)$ & None & None & None \\
\hline $4(15)$ & None & None & None \\
\hline \multicolumn{4}{|l|}{ MCD2 } \\
\hline $1(10)$ & None & Site Plan Checklist & None \\
\hline $2(13)$ & Stormwater & None & $\begin{array}{l}\text { Outside engineering } \\
\text { consultant used to } \\
\text { address stormwater } \\
\text { concerns }\end{array}$ \\
\hline $3(16)$ & None & $\begin{array}{l}\text { Stormwater; lake } \\
\text { water quality }\end{array}$ & $\begin{array}{l}\text { Stormwater management } \\
\text { plan; use of treatment } \\
\text { train for stormwater } \\
\text { (settling basin and } \\
\text { wetland sequence) }\end{array}$ \\
\hline $4(11)$ & Wetlands & $\begin{array}{l}\text { Wetlands; lake } \\
\text { water quality }\end{array}$ & $\begin{array}{l}\text { Wetland dredging not } \\
\text { allowed }\end{array}$ \\
\hline \multicolumn{4}{|l|}{ MCD3 } \\
\hline $1(8)$ & Storm drainage & Site Plan Checklist & Catch basins installed \\
\hline $2(15)$ & Street runoff & Wetlands & $\begin{array}{l}\text { Wetland areas deemed too } \\
\text { small to regulate and } \\
\text { received runoff }\end{array}$ \\
\hline $3(13)$ & $\begin{array}{l}\text { Hazardous waste from } \\
\text { railroad; trees; } \\
\text { basement flooding; } \\
\text { wetlands }\end{array}$ & None & $\begin{array}{l}\text { Graded to utilize catch } \\
\text { basin; additional } \\
\text { stormdrain installed }\end{array}$ \\
\hline $4(14)$ & $\begin{array}{l}\text { Drainage; wetlands; } \\
\text { parks and open space }\end{array}$ & $\begin{array}{l}\text { Catch basins; } \\
\text { storm sewers; } \\
\text { floodplain; } \\
\text { erosion control }\end{array}$ & $\begin{array}{l}\text { Installation of rip-rap for } \\
\text { erosion control; new } \\
\text { storm drain and } \\
\text { easement }\end{array}$ \\
\hline \multicolumn{4}{|l|}{ MCD4 } \\
\hline $1(10)$ & None & None & Soil erosion violation \\
\hline $2(10)$ & None & None & Site plan processing form \\
\hline $3(6)$ & None & $\begin{array}{l}\text { Wetland } \\
\text { delineation }\end{array}$ & None \\
\hline $4(9)$ & None & None & None \\
\hline
\end{tabular}

planning commission. Surface water issues, including wetlands, drainage, and flooding dominate the concerns and responses of the citizens and public officials.
A summary comparison between the site evaluation scores and the different concerns and responses is shown in Table 7 . The rows of this table were derived 
Table 7. Comparison of concerns/responses to mean site evaluation scores ( $N=16$ sites)

\begin{tabular}{lcccc}
\hline & $\begin{array}{c}\text { No } \\
\text { response }\end{array}$ & Mean & Actual concern/response & Mean \\
\hline A. Citizen concerns & $9 / 16$ & 10.8 & $7 / 16$ & 11.4 \\
B. Planning commission concerns & $9 / 16$ & 9.3 & $7 / 16$ & 11.4 \\
C. Response & $7 / 16$ & 9.6 & $9 / 16$ & 12.2 \\
\hline
\end{tabular}

from columns 2-4 of Table 6, and the values for each cell represent the counts of "none" (for no response) or actual response actions occurring at the 16 evaluated sites.

The figures in Table 7 show that higher site evaluation scores exist for those developments where there were concerns raised by the public or the planning commission during project review. For example, at 9 of 16 sites where there were no citizen concerns, the mean score was 10.8 (below the grand mean of 11.6), as opposed to the mean score of 11.4 at the seven sites where there were concerns. Similarly, without the planning commission concerns, the mean site evaluation scores are also below the grand mean and the mean score of sites where there were concerns. A Student's $t$ test performed on these means was not significant; however, increasing mean scores are associated with an input of response. As would be expected, actual response (item C) creates the greatest increase in the site evaluation mean scores (from 9.6 to 12.2), whereas planning commission concerns are more effective in raising the mean site evaluation scores (from 9.3 to 11.4) than citizen concerns (from 10.8 to 11.4 ).

\section{Discussion}

The pattern of site evaluation scores within communities corresponds to the pattern characterizing recent and current environmental management within the United States. That is, response is reactive based on visible events, and not proactive-a pattern established since the 1930s. For example, flood control legislation (the 1936 Flood Control Act) followed large floods on the Mississippi River during the late 1920s and early 1930s. Later, the legal and administrative foundations for environmental protection-the National Environmental Policy Act of 1969 and the establishment of the Environmental Protection Agency in 1970-followed significant environmental disasters (the Cuyahoga River fire in Ohio and the Santa Barbara oil spill off the coast of California).

The planning response to visible environmental features at the subdivision scale parallels the legal and administrative responses at the national scale to large- scale environmental disasters. At the small geographic scale of this study, site evaluation scores are highest within communities containing the most significant and visible water features (MCD2 and MCD3). Visible water resources seem to provide an incentive for protection, with response lacking in areas without them.

Beyond this broad comparison, there are two critical factors contributing to the lack of effective environmental management at the small development scale. These factors include: (1) the lack of scientific and geographic specificity of the environmental ordinances enacted at the state level and applied locally, and (2) the lack of local expertise in critical environmental management areas, most notably ecology and erosion control.

With respect to scientific and geographic specificity, the state-level ordinances for wetland protection and erosion control fail in several areas. The GoemeareAnderson Wetland Protection Act excludes wetlands less than 5 acres from regulation, unless: (1) there is a surface connection to an inland lake or stream, (2) they are within $500 \mathrm{ft}$ of an inland lake or stream, or (3) they are within 1000 feet of the Great Lakes-a condition not applicable to this study region. As a result, many small wetland areas are filled during development. In an investigation focusing on only a two-year period (1995-1996), a significant amount of wetlands (>10\%) were removed within two of the four communities in this study (Kaufman 1996).

Michigan's erosion control law does not mandate a soil sample at each construction site, nor does it specify when site inspections of erosion control best management practices should occur. Without knowing the soil type, developers use filter fences not matched to a specific soil. This results in lower efficiency of the fence and quite often their complete failure (Kaufman 2000). Moreover, the failure to require at least one erosion control evaluation after a precipitation event prevents the proper evaluation of the control measures when they are put to their true test.

The lack of local expertise in critical environmental areas is exemplified by the absence of citizen and planning commission concerns at over half of the sites in this investigation. In matters related to erosion control 
and ecology, there was very poor performance. The poor erosion control results are characterized by only one in 16 developments performing any positive soil management action and the generally poor performance on slope management.

Pertaining to ecological management, the "site plan processing form" and "site plan checklist" noted in Table 6 illustrate part of the problem. Each form was dominated by structural engineering controls such as storm drains and detention facilities, or architectural/ zoning concerns involving lighting, parking, structural dimension, and traffic flow. There were no specific items concerning wildlife habitat, preservation of native vegetation, or the protection of sensitive land.

Another factor contributing to the failure to manage site ecology properly is the lack of a comprehensive state-wide environmental framework. This framework would recognize the ecological integration of the atmosphere, biosphere, hydrosphere, and lithosphere and provide performance standards for the maintenance of these systems' quality. For example, a provision for maintaining the predevelopment runoff levels from a site after it was developed could also include measures to control erosion and sedimentation.

\section{Conclusions}

Lacking a comprehensive environmental management framework and scientific expertise, local communities have responded in a fragmented manner, copying the existing state ordinances without regard for their local environmental conditions. Where local ordinances have been enacted, they are based on a delayed response to new information in specific areas and lack any broad ecological cohesion. Some response is spurred by the existence of visible water features, but the low scores indicate that the concern over water features does not translate into the comprehensive environmental management of site developments.

Key factors contributing to the poor status of local environmental management are the failure to recognize the variability of the physical processes occurring at different geographic scales and the lack of local expertise within communities. This lack of expertise is a negative side effect from the poor state-level environmental framework, as communities lack the guidance necessary to determine a proper level of environmental analysis required at small geographic scales.

Despite this lack of state guidance, local planning commissions reviewing and approving site plans still have a key role in local environmental management. Improvement can be achieved through the education of commission members about environmental con- cerns during subdivision development. Consulting a checklist of environmental performance standards similar to the evaluation criteria specified within this paper is one possible mechanism. Another option to improve the environmental management at site developments would be a postproject review performed by the drain commissioner or another party outside of the community.

\section{Acknowledgments}

The research was made possible by a grant from the Research Excellence Fund at the University of Michigan-Flint.

\section{Literature Cited}

Barrett, M. E., J. F. Malina, Jr., and R. J. Charbeneau. 1998. An evaluation of geotextiles for temporary sediment control. Water Environment Research 70:283-290.

Betson, R. P. 1964. What is watershed runoff? Journal of Geophysical Research 69:1541-1552.

Brookes, A., and F. D. Shields (eds.). 1996. River channel restoration: Guiding principles for sustainable projects. John Wiley \& Sons, New York.

Brookes, A., K. J. Gregory, and F. H. Dawson. 1983. An assessment of river channelization in England and Wales. The Science of the Total Environment 27:97-112.

Burian, S. J., S. J. Nix, S. R. Durrans, R. E. Pitt, C. Fan, and R. Field. 1999. Historical development of wet-weather flow management. Journal of Water Resources Planning and Management 125:3-13.

Cape, J. N., A. H. F. Brown, S. M. C. Robertson, G. Howson, and I. S. Paterson. 1991. Interspecies comparisons of throughfall land stemflow at three sites in northern Britain. Forest Ecology and Management 125:165-177.

Crozier, M. J. 1984. Field assessment of slope instability. Pages 103-142 in D. Brunsden and D. B. Prior (eds.), Slope instability. John Wiley \& Sons, New York.

Dickman, C. R. 1987. Habitat fragmentation and vertebrate species richness in an urban environment. Journal of Applied Ecology 24:337-351.

Dorr, J. A., and D. F. Eschman. 1970. Geology of Michigan. University of Michigan Press, Ann Arbor.

Goldman, S. J., K. Jackson, and T. A. Bursztynsky. 1986. Erosion and sediment control handbook. McGraw-Hill, New York.

Graf, W. 1975. The impact of suburbanization on fluvial geomorphology. Water Resources Research 11:690-692.

Hagman, D. G. 1975. Urban planning and land development control law. West Publishing, St. Paul, Minnesota.

Hall, M. J., and J. B. Ellis. 1985. Water quality problems in urban areas. GeoJournal 11:265-275.

Holcomb, S. 1993. Soil survey of Genesee County, Michigan. 
US Department of Agriculture, Soil Conservation Service. US Government Printing Office, Washington, DC.

Hooke, J. M. 1986. Applicable and applied geomorphology of rivers. Geography 71:1-13.

Kaufman, M. M. 1995. Community response to stormwater pollution in an urbanized watershed. Water Resources Bulletin 31:3:491-504

Kaufman, M. M. 1996. Regional growth study. Regional Groundwater Center, University of Michigan-Flint, Flint, Michigan.

Kaufman, M. M. 1999. Micro-topographic opportunities for stormwater management in urban landscapes. Pages 86-95 in Papers and Proceedings of the Applied Geography Conferences, 13-16 October 1999, Charlotte, North Carolina.

Kaufman, M. M. 2000. Erosion control at construction sites: The science-policy gap. Environmental Management 26:1:89-97.

Kaufman, M. M., and W. M. Marsh. 1997. Hydro-ecological implications of edge cities. Landscape and Urban Planning $36: 277-290$

Kaufman, M. M., and M. Wurtz. 1997. Hydraulic and economic benefits of donwspout diversion. Journal of the American Water Resources Association 33:491-497.

Lowell, K. E., R. J. Mitchell, and P. S. Johnson. 1987. Predicting growth and "success" of coppice-regenerated oak stems. Forest Science 33:740-749.
Marsh, W. M. 1996. Environmental geography. John Wiley \& Sons, New York.

MCL. 2000. Michigan compiled laws annotated. West Publishing, St. Paul, Minnesota.

McCuen, R. H., and G. E. Moglin. 1988. Multicriterion stormwater management methods. Journal of Water Resources Planning and Management 114:414-431.

Mitsch, W. J., and J. G. Gosselink. 1993. Wetlands, 2nd ed. Van Nostrand Reinhold, New York.

Moll, G. 1988. From planting to politics: improving the health of the urban forest, part II. American Forests 94:45-48.

Myers, M. A., and G. F. White. 1993. The challenge of the Mississipppi flood. Environment 35:6-9.

Ortolano, L. 1984. Environmental planning and decision making. John Wiley \& Sons, New York.

Pimental, D., J. Allen, and A. Beers. 1987. World agriculture and soil erosion. Bioscience 37:277-283.

Wigston, D. L. 1980. Ecological aspects of woodland management and forestry practice. Nature in Devon 1:47-70.

Wolman, M. G. 1967. A cycle of sedimentation and erosion in urban river channels. Geografiska Annaler 49A:385-395.

Yoshida, T., and K. Tomohiko. 1997. The stand dynamics of a mixed coppice forest of shade-tolerant and intermediate species. Forest Ecology and Management 95:35-43. 